Bangladesh J. Zool. 42(1): 85-90, 2014

\title{
NECTAR FEEDING BEHAVIOR OF SOME BUTTERFLIES IN THE BOTANICAL GARDEN OF DHAKA UNIVERSITY
}

\author{
Murshida Begum*, Ummey Habiba and Moksed Ali Howlader \\ Department of Zoology, University of Dhaka, Dhaka-1000, Bangladesh
}

\begin{abstract}
Nectar feeding behavior of butterflies belonging to the families Nymphalidae, Danaidae, Pieridae, Lycaenidae and Papilionidae were studied in the Botanical garden of Dhaka University. The highest and the lowest duration of searching time was $39 \pm 2$ and $36 \pm 5$ seconds respectively for the Catopsila pomona and Zizina otis. The highest and the lowest duration of feeding was $13.0 \pm$ 1 and $9.9 \pm 0.9$ seconds respectively for the Danaus chrysippus and Zizina otis. The longest proboscis $(12.6 \pm \mathrm{mm})$ was recorded in Danaus chrysipus. The deepest corolla $(22 \pm 5 \mathrm{~mm})$ was found in the flower of Cosmos bipinnatus plants. The proboscis of 4 butterfly species named Eurema hecabe, Jononia almana, Catochrysopes strabo and D. chrysipus was highly correlated with the corolla tube of Cosmos bipinnatus, Tephrosia purpurea and Tagetes erecta repectively.
\end{abstract}

Key words: Butterflies, nectar feeding, proboscis, corolla.

\section{INTRODUCTION}

Butterflies are ecologically diverse group of insects showing complex foraging behavior during searching for food and nectar (Sourakov et al., 2012). The nectar of flower is the main source of adult nutrition (Ômura and Honda, 2005). The butterflies exhibit distinct differences for flower preference (Jennersten, 1984). They choose plants as nectar sources depending on various factors including colors and odors of flowers (Jolivet 1986, Weiss 1997, Dosa 1999, DeVries et al., 1999 and Sourakov 2012). Odor sometimes acts as a synergist with color as the important cue of foraging (Ômura and Honda, 2005). The floral scent is a vital signal used by butterflies initially to identify and subsequently to recognize and distinguish among worthwhile plants (Andersson, 2003).

The usefulness of butterfly foraging depends on the corolla depth and proboscis length which limits the range of flowers from which nectar can be extracted (Porter et al., 1992 and Corbet, 2000). Although a good number of researches were conducted on morphology and taxonomy of different butterfly species in Bangladesh but works on the nectar feeding behavior of adult butterflies are not available. Therefore, the objectives of the present investigation are to study the nectar feeding behavior of different butterfly species including the relationship between the corolla depth and the proboscis lengths of some adult species.

*Author for correspondence: murshida1972@yahoo.com 


\section{MATERIAL AND METHODS}

The study was conducted in the Botanical garden of Dhaka University during March, 2011 to February, 2012.

Ten species of butterflies belonging to five different families were selected for the present study. The flowering plants of the garden were observed to record the nectar feeding behavior of the selected butterflies. During the observation, each nectar plant was observed for ten minutes at a time for the visit (if any) at intervals of a period of 8 hours starting from 8 am to $4 \mathrm{pm}$ once in each month. The records were maintained as the duration of searching for a suitable flower and the duration for nectar feeding by each day. The records were also kept on the number of species of butterflies visited the host plant during the whole period of study. The nectar searching period was observed on the basis of the time during which a butterfly remained on wing near the host plant or hovering over the host plants before sitting on a flower for nectar feeding. The duration of feeding was counted from the moment of dipping the proboscis into the flower corolla till the moments of its withdrawal. 'Tukey's honest significance test' was accomplished to compare the duration of searching for food and the duration of feeding of different butterfly species.

The depth of corolla tube of the flowers and the lengths of the proboscis of the butterflies were measured in millimeter. Four species of butterflies named, Eurema hecabe, Catochrysops stabo, Junonia almana and Danaus chrysippus were selected for this study. Simple linear regression lines were produced by comparing the data of corolla depths of flowers and the proboscis lengths of the respective butterflies using Microsoft Excel version 2010.

\section{RESULTS AND DISCUSSION}

Eight families of flowering plants were noted to be visited by 10 species of butterflies (Table1). The family Compositae comprised of two species of plants Cosmos bipinnatus (Cosmos) and Eupatorium odoratum (Asam lata) which were foraged by mximum 9 species of butterflies named Catopsila pomona, $C$. pyranthe, D. chrysippus, E. blanda, E. hecabe, J. almana, J. atlites, Leptosia nina and Papilio polytes. The family Verbenaceae contained the species of Clerodendrum infortunatum (Bhat) and Lantana camara (Lantana), foraged by 8 individuals of butterflies. Individuals of 7 species of butterflies were noted to take nectar from two species of plants Tagetes erecta (Gada) and Zinnia elegans (Zinia) under the family Asteraceae. The plants of Gomphrena pulchela (Botamphul) family Amaranthaceae was visited by 6 species of butterflies. The family Labiateae was represented by Salvia sp. which is attracted by the butterflies of 6 species. The family Viticeae has one species Vitis lanceolaria 
(Harina lata) which was also visited by 6 butterfly species. The family Apocynaceae is represented by a single species Rauwlfia serpentina (Sarpogandha) which was also foraged by 5 species of butterflies. The plants belong to the famiy Viticeae are climbers, Apocynaceae are herbs and the others are shrubs.

Table 1. Plants used for nectar feeding by different butterflies

\begin{tabular}{|c|c|c|c|c|}
\hline \multicolumn{4}{|c|}{ Name of Plants } & \multirow[t]{2}{*}{ Name of Butterflies } \\
\hline $\begin{array}{l}\text { Common } \\
\text { name }\end{array}$ & Scientific name & Family name & Type & \\
\hline Asam lata & $\begin{array}{l}\text { Eupatorium } \\
\text { odoratum }\end{array}$ & Compositae & Shrub & $\begin{array}{l}\text { Catopsila pyranthe, C. pomona, } \\
\text { Danaus chrysippus, Eurema } \\
\text { blanda, E. hecabe and Zizina } \\
\text { otis. }\end{array}$ \\
\hline Cosmos & $\begin{array}{l}\text { Cosmos } \\
\text { bipinnatus }\end{array}$ & Compositae & Shrub & $\begin{array}{l}\text { E. blanda, E. hecabe, Junonia } \\
\text { almana, J. atlities, Leptosia nina } \\
\text { and } Z \text {. otis. }\end{array}$ \\
\hline Bhat & $\begin{array}{l}\text { Clerodendrum } \\
\text { infortunatum }\end{array}$ & Verbenaceae & Shrub & $\begin{array}{l}\text { D. chrysippus, E. blanda, E. } \\
\text { hecabe, Papilio polytes and } Z \text {. } \\
\text { otis,. }\end{array}$ \\
\hline Lantana & Lantana camara & Verbenaceae & Shrub & $\begin{array}{l}\text { C. pomona, C. pyranthe, } E \text {. } \\
\text { blanda, E. hecabe, L. nina and } \\
\text { P. polytes }\end{array}$ \\
\hline Gada & Tagetes erecta & Asteraceae & Shrub & $\begin{array}{l}\text { C. pyranthe, C. pomona, } D . \\
\text { chrysippus, } J . \text { almana, J. } \\
\text { atlities, L. nina, and } P . \text { polytes. }\end{array}$ \\
\hline Zinnia & Zinnia elegans & Asteraceae & Shrub & $\begin{array}{l}\text { C. pyranthe, } C \text {. pomona, } J . \\
\text { almana, J. atlities, L. nina and } \\
P . \text { polytes. }\end{array}$ \\
\hline Botamphul & $\begin{array}{l}\text { Gomphrena } \\
\text { pulchela }\end{array}$ & Amaranthaceae & Shrub & $\begin{array}{l}\text { D. chrysippus, E. blanda, E. } \\
\text { hecabe, J. almana, J. atlities } \\
\text { and } Z \text {. otis }\end{array}$ \\
\hline Salvia & Salvia sp. & Labiateae & Shrub & $\begin{array}{l}\text { E. blanda, E. hecabe, J. } \\
\text { almana, J. atlities, L. nina and } \\
\text { Z. otis. }\end{array}$ \\
\hline Harina Lata & Vitis lanceolaria & Viticeae & Climber & $\begin{array}{l}\text { C. pyranthe, C. pomona, } E \text {. } \\
\text { blanda, E. hecabe, L. nina and } P \text {. } \\
\text { polytes. }\end{array}$ \\
\hline Sarpogandha & $\begin{array}{l}\text { Rauwlfia } \\
\text { serpentina }\end{array}$ & Apocynaceae & Herb & $\begin{array}{l}\text { C. pomona, C. pyranthe, } E \text {. } \\
\text { blanda, E. hecabe, and } Z \text {. otis. }\end{array}$ \\
\hline
\end{tabular}

The duration of nectar searching and the duration of feeding are shown in Table 2. The longest duration of nectar searching was $39.33 \pm 2.1$ seconds for $C$. pomona and the shortest $(36.1 \pm 4.5 \mathrm{sec}$.) for $Z$. otis. The highest and the lowest duration of feeding were $13.0 \pm 1.4$ and $9.9 \pm 0.9$ seconds respectively, for the $D$. chrysipus and $Z$. otis.

The present study indicated that the maximum numbers of butterflies were attracted to the yellow and violet flowers. These findings agree with the work of Bakowsk and Boron (2005). However, Goulson and Cory, (1993), mentioned that floral colors and scent together exerts important signals for foraging. According to Dover, (1989), representatives of the family Pieridae and Nymphalidae need 
more time to drink nectar. In the present study Catopsilia pomona (Family Pieridae) took more time to search water and Junonia almana (Family Nymphalidae) need more time to feed nectar (Table 2).
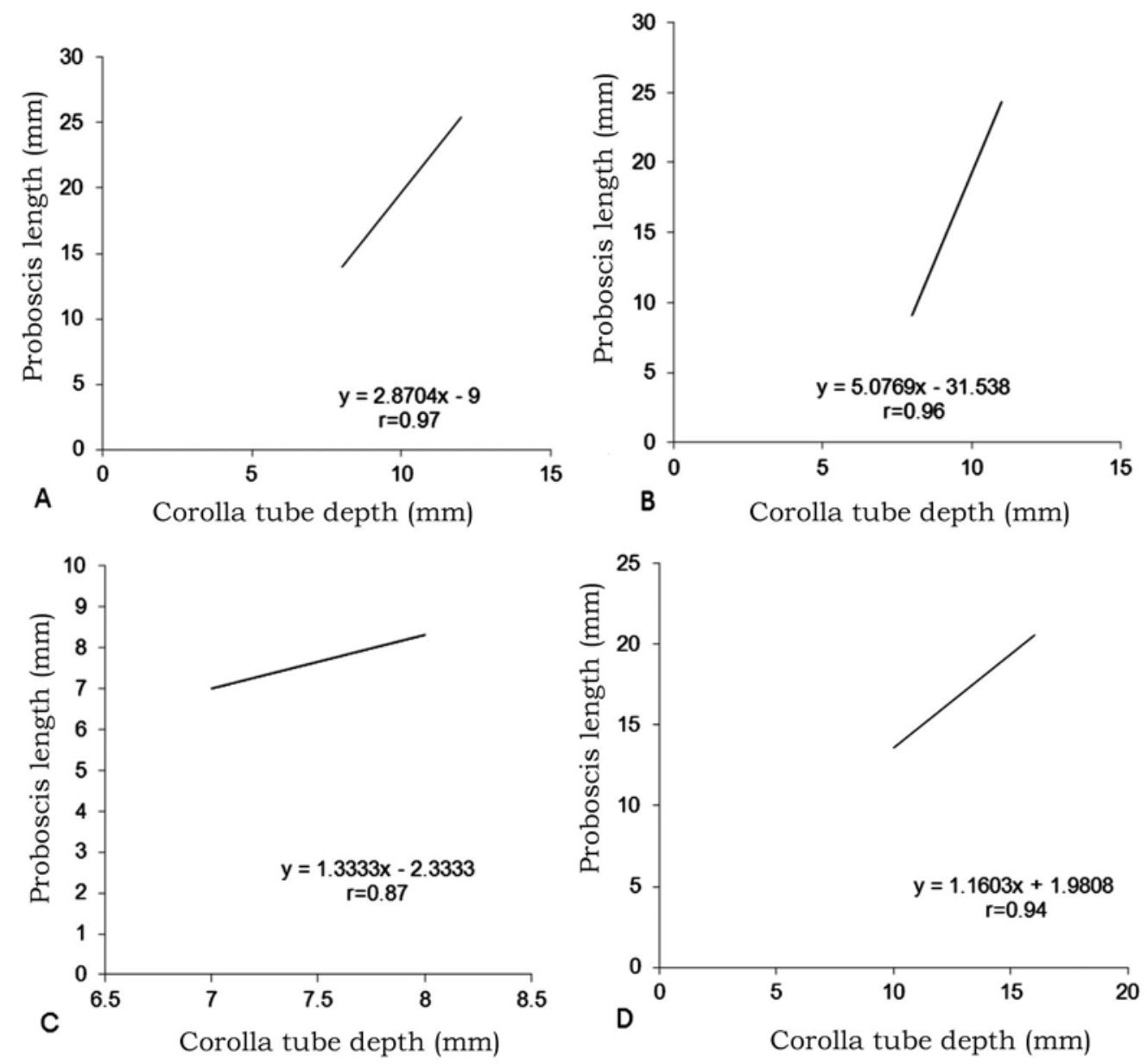

Fig. 1. Relation between Corolla tube depth and Proboscis length of four butterflies foraged in four flowers. A. Eurema hecabe and Cosmos bipinnatus. B. Junonia almana and Cosmos bipinnatus. C. Catochrysopes strabo and Tephrosia purpurea. D. Danaus chrysippus and Tagetes erecta.

Relationships between the proboscis lengths of four selected species of butterflies and the corolla tube depths of the specific flowers are presented in Figure1. Results indicated that the proboscis lengths of the selected butterflies were largely correlated with the depth of corolla of respective host plant. It is often assumed that long tongued species of butterflies (Nymphalidae and Pieridae) prefer to forage more nectar producing plants (Bakowsk and Boron, 2005). In the present study proboscis length of E. hecabe (Family - Pieridae), $J$. almana (Family- Nymphalidae) and D. chrysipus (Family- Danaidae) were highly 
Table 2. Nectar searching and nectar feeding time (Seconds) of butterflies at different temperatures

\begin{tabular}{lccc}
\hline Name of foragers & $\begin{array}{c}\text { Duration of feeding } \\
\text { (second) } \\
\text { (Mean } \pm \mathrm{SD} \text { ) }\end{array}$ & $\begin{array}{c}\text { Duration of } \\
\text { searching (second) } \\
\text { (Mean } \pm \mathrm{SD} \text { ) }\end{array}$ & $\begin{array}{c}\text { Temperature }\left({ }^{\circ} \mathrm{C}\right) \\
\text { (Mean } \pm \mathrm{SD} \text { ) }\end{array}$ \\
\hline Jononia almana & $12.9 \mathrm{a} \pm 0.3$ & $38.8 \mathrm{a} \pm 2.7$ & $25.2 \pm 1.6$ \\
Junonia atlites & $11.9 \mathrm{~b} \pm 0.7$ & $37.8 \mathrm{~b} \pm 2.2$ & $24.0 \pm 1.0$ \\
Eurema blanda & $10.7 \mathrm{c} \pm 1.0$ & $37.2 \mathrm{~b} \pm 4.1$ & $23.6 \pm 1.2$ \\
Eurema hecabe & $10.8 \mathrm{c} \pm 1.4$ & $37.1 \mathrm{~b} \pm 4.1$ & $23.5 \pm 1.3$ \\
Catopsila pyranthe & $10.5 \mathrm{c} \pm 0.8$ & $38.7 \mathrm{a} \pm 2.7$ & $24.3 \pm 1.0$ \\
Catopsila pomona & $11.7 \mathrm{~b} \pm 1.2$ & $39.3 \mathrm{a} \pm 2.8$ & $23.5 \pm 0.5$ \\
Zizina otis & $9.9 \mathrm{~d} \pm 0.9$ & $36.1 \mathrm{c} \pm 2.1$ & $23.8 \pm 0.98$ \\
Leptosia nina & $10.9 \mathrm{c} \pm 1.5$ & $36.8 \mathrm{c} \pm 4.5$ & $24.5 \pm 1.6$ \\
Danaus chrysippus & $13.0 \mathrm{a} \pm 1.4$ & $37.8 \mathrm{~b} \pm 2.6$ & $23.0 \pm 0.8$ \\
Papilio polytes & $10.3 \mathrm{~d} \pm 2.4$ & $36.6 \mathrm{c} \pm 2.1$ & $24.2 \pm 1.1$ \\
\hline
\end{tabular}

$\mathrm{N}=$ feeding and searching bouts in each species. Mean indicated by different letters are significantly different from each other.

correlated with the corolla tube depth of Cosmos bipinnatus (Family Compositae) and Tagetes erecta (Family - Asteraceae). All the butterfly species studied were strongly associated with the plant family Compositae, Verbenaceae and Asteraceae.

\section{LITERATURE CITED}

ANDERSON, S 2003. Antennal responses to floral scents in the butterflies Inachis io, Aglais urticae (Nymphalidae) and Gonepteryx rhamni (Pieridae). Chemoecology. 13(1): 13 -20.

BAKOWSK, M. and BORON, M. 2005 Flower visitation pattern of some species of Lycaenidae (Lepidoptera). Biol. lett. 42(1): 13-19.

CORBET, S.A. 2000. Butterfly nectaring flowers: butterfly morphology and flower form. Entomol. Exp. Appl. 96:289-298.

DEVRIES, P.J., WALLA, T.R. and GREENEY, H.F. 1999. Species diversity in spatial and temporal dimensions of fruit - feeding butterflies from two Ecuadorian rainforests. Biol. J. Linn. Soc. 68: 333-353.

DOSA, G. 1999. Flower visitation pattern of butterflies and burnet moths in the aggtelek - karst (Hungary). Nota lepid. 22:58 - 66.

DOVER, J. 1989. The use of flowers by butterfly foraging in cereal field margins. Entomologist's Gaz. 40:283-291.

EK- AMNUAY, P. 2006. Butterflis of Thailand. 1: 1-944. American printing and publishing Co. limited, Chaiyaphrok road, Taling chan, Bangkok.

GOULSON, D. and CORY, J.S. 1993. Flower constancy and learning in the foraging behaviour of the green-veined white butterfly, Pieris napi. Ecol. Entmol. 18 (4): 315-320.

JENNERSTEN, O. 1984. Flower visitation and pollination efficiency of some north European butterflies. Onecologia. 63: 80-89.

JOLIVET, P. 1986. Insects and plants. Flora and fauna hand book, no.2. E.J. Brill Flora and Fauna Publications, USA.

KRENN, H.W., ZULKA, K. P. and GATSCHN T. 2001. Proboscis morphology and food preferences in nymphalid butterflies (Lepidoptera: Nymphalidae). J. Zool. 254(1): 17-26. 
ÔMURA and HONDA. 2005. Priority of color over scent during flower vegetation by adult Venessa indica butterflies. Onecologia. 142(4): 588-596.

PORTER, K., STEEL, C.A. and THOMAS, J. A. 1992. Butterflies and communities. In: The ecology of butterflies in Britain (Dennis R.L.H., ed). University Prss, Oxford, New York, Tokyo. pp. 139-177.

SOURAKOV, A., DUEHL, A. and SOURAKOV, A. 2012. Foraging behavior of the blue morpho and other tropical butterflies: The chemical and electrophysiological basis of olfactory preferances and the role of color. Psyche. 2012: 1-10.

WEISS, M.R. 1997. Innate colour preferences and flexible colour learning in the pipevine swallow tail. Animal Behav. 65: 425-434.

(Manuscript received on 10 January 2014; revised on 2 June 2014) 